\section{REFERENCES}

Anthonisen, N. R., Bass, H., Oriel, A., Place, R. E. G., and Bates, D. V. (1968). Clinical Science, 35, 495.

Bates, D. V., and Christie, R. V. (1950). Clinical Science, 9, 17

Bentivoglio, L. G. et al. (1963). American Review of Respiratory Diseases, 88, 315 .

Brown, I. K., Kirk, F., and Seaton, A. (1969). British fournal of Radiology, 42, 545 .

Burrows, B., Fletcher, C. M., Heard, B. E., Jones, N. L., and Wootliff, J. S. (1966). Lancet, 1, 830.

Dollery, C. T., and Gillam, P. M. S. (1963). Thorax, 18, 316.

Fletcher, C. M., Hugh-Jones, P., McNicol, M. W., and Pride, N. B. (1963). Quarterly fournal of Medicine, 32, 33.

Fletcher, C. M., Jones, N. L., Burrows, B., and Niden, A. H. (1964). American Review of Respiratory Diseases, 90, 1 .

Heard, B. E. (1959). Thorax, 14, 58.

Heppleston. A. G., (1968) In Form and Function in the Human Lung, edited by G. Cumming and L. B. Hunt, p. 18. Edinburgh, Livingstone.

Heppleston, A. G., and Leopold, J. G. (1961). American fournal of Medicine, 31, 279.
Hugh-Jones, P., Ritchie, B. C., and Dollery, C. T. (1966). British Medical fournal, 1, 1133

Laws, J. W., and Heard, B. E. (1962). British fournal of Radiology, 35,

Milic-Emili, J., Henderson, J. A. M., Dolovich, M. B., Trop, D., and Kaneko, K. (1966). Fournal of Applied Physiology, 21, 749.

Mitchell, R. S., Ryan, S. F., Petty, T. L., and Filley, G. F. (1966) American Review of Respiratory Diseases, 93, 720.

Mitchell, R. S., Vincent, T. N., Ryan, S., and Filley, G. F. (1964) American fournal of the Medical Sciences, 247, 513.

Ogilvie, C. (1967). Thorax, 22, 286.

Ogilvie, C., and Catterall, M. (1959). Thorax, 14, 216.

Ogilvie, C. M., Forster, R. E., Blakemore, W. S., and Morton, J. W. (1957). Fournal of Clinical Investigation, 36, 1.

Pain, M. C. F., Glazier, J. B., Simon, H., and West, J. B. (1967) Thorax, 22, 453.

Reid, L., and Millard, F. J. C. (1964). Clinical Radiology, 15, 307.

West, J. B. (1966a). In Ciba Foundation Symposium Development of the Lung, edited by A. V. S. de Reuk and R. Porter, p. 176. London, Churchill.

West. J. B. (1966b). The Use of Radioactive Materials in the Study of Lung Function. Amersham, Radiochemical Centre.

\title{
Use of a One-man, Mobile Pressure Chamber in the Treatment of Carbon Monoxide Poisoning
}

\author{
J. N. NORMAN, ${ }^{*}$ M.D., PH.D., F.R.C.S.; J. MACINTYRE, $\dagger$ M.B., CH.B.; J. R. SHEARER, $\ddagger$ M.B., CH.B.
}

G. SMITH, $囚$ M.D., CH.M., F.R.C.S.

British Medical fournal, 1970, 2, 333-334

Cummary: For the past five years a mobile pressure chamber has been used to treat patients suffering from severe carbon monoxide poisoning with oxygen at 2 atmospheres pressure. Of the 25 patients treated, 20 recovered completely and only three died. This apparatus could also be used for hyperbaric oxygen therapy in other conditions for which it is indicated.

\section{Introduction}

It was shown by Haldane (1895) that carbon monoxide is not itself toxic and that its lethal effects are produced purely by blocking haemoglobin and causing anoxia. Though the action of carbon monoxide in the body has subsequently been shown to be rather less simple, it is still generally agreed that the fundamental aim in the treatment of carbon monoxide poisoning is the same as that of any other anoxic lesionnamely, to cut short the anoxia (Marriott, 1955a, 1955b). In carbon monoxide anoxaemia it is important that the blood should be rid of carbon monoxide by the most rapid and efficient means possible since undue delay in restoring tissue oxygenation may result in brain damage, particularly of the extrapyramidal system. In routine practice this is achieved by the administration of $5 \% \mathrm{CO}_{2}$ in oxygen (Killick and Marchant, 1959; Douglas et al., 1961; Norman, Douglas, and Smith, 1966). It has, however, been known for many years that if ogygen at 2 atmospheres pressure is breathed in carbon monoxide poisoning then carbon monoxide is removed from the blood much more rapidly than when carbon dioxide/oxygen mixtures are breathed at atmospheric pressure. (End and Long, 1942; Pitts and Pace, 1949; Douglas et al., 1962). When a patient breathes oxygen at 2 atmospheres pressure the extra oxygen dissolved in the plasma bypasses the blocked haemoglobin and immediately corrects the state of tissue hypoxia. Thus the benefit of using hyperbaric oxygen in carbon monoxide poisoning is twofold, the rapid dissociation of carboxyhaemoglobin being secondary to the immediate correction of tissue hypoxia.

The use of oxygen at 2 atmospheres pressure in resuscita-

* Senior Lecturer in Surgery.

†Registrar in Surgery.

$\ddagger$ Research Fellow in Surgery.

§Regius Professor of Surgery.

gDepartment of Surgery, University of Aberdeen, Aberdeen AB9 2ZD. tion from carbon monoxide poisoning has been shown to be an efficient means of therapy (Smith and Sharp, 1960; Smith, Ledingham, Sharp, Norman, and Bates, 1962; Norman and Ledingham, 1967), but this facility is available only to those who live within easy access of a hyperbaric unit, and there are few of these units. Smith (1962) suggested the use of an inexpensive, mobile, hyperbaric chamber which could if necessary be taken to the patient in an ambulance or which could be used in centres where large hyperbaric units were not available.

This report deals with our experience during the past five years in the treatment of those cases of severe carbon monoxide poisoning which occurred in the Aberdeen area. A moderately priced, mobile pressure chamber designed by ourselves in association with Normalair Ltd. was used throughout.

\section{Procedure}

Patients suffering from carbon monoxide poisoning who were unconscious on admission to the casualty department of Aberdeen Royal Infirmary were transferred to the hyperbaric unit for treatment. After initial assessment, which included a brief examination of the cardiorespiratory and nervous systems and the removal of a specimen of venous blood for the measurement of the carboxyhaemoglobin concentration, an endotracheal tube was passed, the patient was placed within the mobile pressure chamber (see Fig.), and the pressure was raised to 2 atmospheres absolute with oxygen. By this means the patient was given oxygen at 2 atmospheres pressure to breathe until consciousness returned or until two hours had elapsed. The chamber was then decompressed, and after further clinical examination the patient was transferred to the receiving medical unit, where oxygen at atmospheric pressure was breathed for a further few hours.

Carbon monoxide poisoning has become a less popular method of suicide and most of our cases were accidental, occurring in the older age groups of patients, often living alone and with co-existing atherosclerosis and dimmed senses. Of the 25 patients treated six were aged under 60,13 were 60 to 80 , and six were over 80 . Twenty of the 25 patients recovered completely. Two had residual neurological signs and in these cases a cerebral vascular accident may have preceded the gassing. Of the three patients 


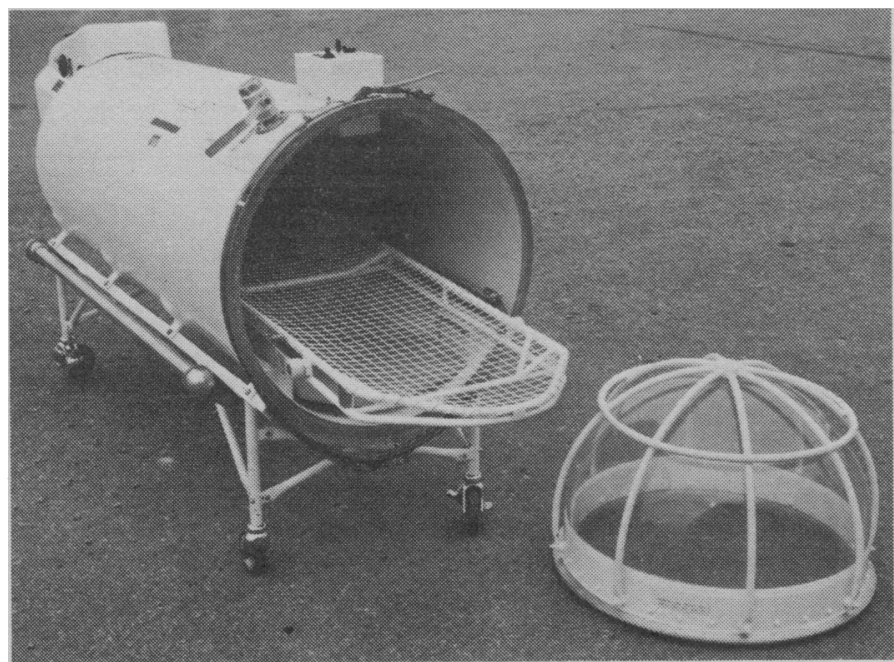

One-man pressure chamber.

who died one was aged 86 , and though she regained consciousness following very severe gassing with aspiration of vomit, she was disorientated for a further three weeks before she died of severe bronchopneumonia. The remaining two patients remained unconscious and died five days and three weeks, respectively, after gassing. The carboxyhaemoglobin levels on admission varied between 5 and $45 \%$, and so far as could be ascertained the time of exposure to the gas varied between half an hour and 14 hours.

The chamber (Fig. 1) is designed to accommodate a patient on a stretcher and to permit pressurization to 2 or 3 atmospheres absolute. It consists of a fibre-glass shell, hemispherical at the foot and fitted with a detachable Perspex dome at the head. The dome is fitted with a protective guard and is attached to the shell by a split-ring clamp. The approximate dimensions are $8 \mathrm{ft}$. $2 \mathrm{in}$. $(2.49 \mathrm{~m}$.) long, $3 \mathrm{ft}$. 9in. $(1.14 \mathrm{~m}$.) high, and $2 \mathrm{ft}$. 7 in. $(0.63 \mathrm{~m}$.) wide. The weight is in the region of $160 \mathrm{lb}$. $(72.6 \mathrm{~kg}$.). Four castoring wheels enable the chamber to be moved easily on level ground by one attendant, while lifting rails at each side enable the chamber to be lifted by two attendants. It is designed to be transported in a standard ambulance, and can be transported by helicopter.

Pressurization is achieved by means of a gas cylinder, which is attached by means of a flexible hose, and the gas passes from the cylinder, through a regulator, such that minimum compression time to 2 atmospheres absolute is about six minutes. Decompression from 2 atmospheres absolute would normally take six minutes but can be achieved in 15 seconds by means of an emergency decompressurizing valve, located at the head of the chamber, near the clamp ring. If a $120 \mathrm{cu}$. ft. ( $3.4 \mathrm{cu}$. m.) gas cylinder is used it should last 40 minutes, allowing a gas overflow of $0.25 \mathrm{lb}$. (113 g.)/minute. The Perspex dome at the head end allows excellent observation of the patient, and an intercommunication system at the head affords free communication between patient and medical attendant.

This chamber can also be used for treating other conditions, such as traumatic ischaemia, and as an aid to radiotherapy. One-man recompression chambers have also found wide application in Service practice, and they have been used in the Far East, Northern Malasia, and Borneo in the treatment of gas gangrene and traumatic ischaemia resulting from gunshot wounds (J. Watt, personal communication, 1970).
Nearer home such a chamber can be used for transporting scuba divers suffering from decompression sickness to centres where treatment is available.

\section{Discussion}

This chamber has proved eminently satisfactory in the treatment of patients suffering from carbon monoxide poisoning. Since only seriously gassed patients have been treated, and in many cases the patients were very old, the results are good. The controls of the chamber are easy to operate, and it could be operated safely by a person untrained in hyperbaric techniques, such as a nurse, technician, or ambulance worker.

An arbitrary maximum period of treatment of two hours was used, since previous experience with a large series of similar cases (Norman and Ledingham, 1967) had shown that the carboxyhaemoglobin concentration is reduced to insignificant levels following the administration of oxygen at 2 atmospheres pressure for this period of time. This is independent of the initial carboxyhaemoglobin concentration. Many of the patients were still unconscious or semi-conscious at the end of the period of pressurization, but they made a good recovery within the next few days. Vomiting during decompression is one of the hazards of administering hyperbaric oxygen by this means in the treatment of carbon monoxide poisoning and this has been overcome here by passing an endotracheal tube before pressurization. If this or any other emergency situation arises then access to the patient can readily be gained (about 30 seconds) by the use of the emergency decompression lever.

A danger of all pressure chambers compressed with oxygen is fire, which may arise from a spark of static electricity from clothing. In this chamber the main gas supply passes through a silencer and a humidifier pad, which maintains the relative humidity above $55 \%$ in order to minimize the build-up of static electricity. It is also possible to give the patient oxygen to breathe by face-mask, while compressing the chamber with air, thus virtually eliminating fire hazard.

Though this study has been centred on the use of this pressure chamber in carbon monoxide poisoning it would be quite satisfactory in other situations where hyperbaric oxygen is used, such as radiotherapy, peripheral vascular lesions, and ischaemic skin flaps.

We wish to acknowledge the grant made by the Home and Health Department, Scotland, to G. Smith, in order to develop this portable chamber. Our thanks are also due to Dr. D. M. Proctor, who referred most of the patients for treatment.

\section{REFERENCES}

Douglas, T. A., et al. (1961). British Medical fournal, 2, 1673.

Douglas, T. A., et al., (1962). Lancet, 1, 68.

End, E., and Long, C. W. (1942). Fournal of Industrial Hygiene, 24, 302 .

Haldane, J. S. (1895). fournal of Physiology, 18, 201.

Killick, E. M., and Marchant, J. V. (1959). Jourmal of Physiology, 147, 274.

Marriott, H. L. (1955a). British Medical fournal, 1, 664.

Norman, J. Nouglas, T. A. and Smith, G. (1966). fourmal of Applied Physiology, 21, 848.

Norman, J. N., and Ledingham, I. McA. (1967). Progress in Brain Research, 24, 101.

Pitts, G. C., and Pace, N. (1949). Naval Medical Research Institute, Bethesda, Maryland. Project N.M. 001, 056.01.14.

Smith, G. (1962). Annals of Occupational Hygiene, 5, 259.

Smith, G., Ledingham, I. McA., Sharp, G. R., Norman, J. N., and Bates, E. H. (1962). Lancet, 1, 816.

Smith, G., and Sharp, G. R. (1960). Lancet, 2, 905. 